\title{
"The Case of COVID-19 impact on the level of non-performing loans of conventional commercial banks in Indonesia"
}

\begin{tabular}{|c|c|}
\hline \multirow{3}{*}{ AUTHORS } & Siti Epa Hardiyanti ED https://orcid.org/0000-0001-6451-8624 \\
\hline & R https://publons.com/researcher/S-3178-2018 \\
\hline & Lukmanul Hakim Aziz iD https://orcid.org/0000-0002-9498-0251 \\
\hline ARTICLE INFO & $\begin{array}{l}\text { Siti Epa Hardiyanti and Lukmanul Hakim Aziz (2021). The Case of COVID-19 } \\
\text { impact on the level of non-performing loans of conventional commercial banks in } \\
\text { Indonesia. Banks and Bank Systems, 16(1), 62-68. } \\
\text { doi:10.21511/bbs.16(1).2021.06 }\end{array}$ \\
\hline DOI & http://dx.doi.org/10.21511/bbs.16(1).2021.06 \\
\hline RELEASED ON & Wednesday, 24 February 2021 \\
\hline RECEIVED ON & Thursday, 01 October 2020 \\
\hline ACCEPTED ON & Thursday, 03 December 2020 \\
\hline & $((c))$ EY \\
\hline LICENSE & $\begin{array}{l}\text { This work is licensed under a Creative Commons Attribution } 4.0 \text { International } \\
\text { License }\end{array}$ \\
\hline JOURNAL & "Banks and Bank Systems" \\
\hline ISSN PRINT & $1816-7403$ \\
\hline ISSN ONLINE & $1991-7074$ \\
\hline PUBLISHER & LLC "Consulting Publishing Company "Business Perspectives" \\
\hline FOUNDER & LLC "Consulting Publishing Company "Business Perspectives" \\
\hline & $\begin{array}{l}=-: \\
=:-5\end{array}$ \\
\hline NUMBER OF REFERENCES & NUMBER OF FIGURES \\
\hline 23 & 4 \\
\hline
\end{tabular}

(c) The author(s) 2021. This publication is an open access article. 


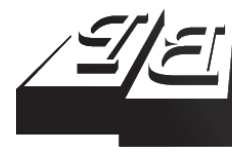

\section{BUSINESS PERSPECTIVES}

(O)

LLC "CPC "Business Perspectives" Hryhorii Skovoroda lane, 10, Sumy, 40022, Ukraine www.businessperspectives.org
Received on: $1^{\text {st }}$ of October, 2020 Accepted on: $3^{\text {rd }}$ of December, 2020 Published on: $24^{\text {th }}$ of February, 2021

(C) Siti Epa Hardiyanti, Lukmanul Hakim Aziz, 2021

Siti Epa Hardiyanti, S2 Master of Management, Lecturer, Economic and Business Faculty, Banking and Finance Department, Sultan Ageng Tirtayasa, Indonesia. (Corresponding author)

Lukmanul Hakim Aziz, S2 Master of Management, Lecturer, Economic and Business Faculty, Banking and Finance Department, Sultan Ageng Tirtayasa, Indonesia.

\section{THE CASE OF COVID-19 IMPACT ON THE LEVEL OF NON-PERFORMING LOANS OF CONVENTIONAL COMMERCIAL BANKS IN INDONESIA}

\begin{abstract}
This study aims to investigate the impact of COVID-19 on the increase in bad credits at conventional commercial banks in Indonesia. The data used in this study are secondary data sourced from the Ministry of Health and from the Financial Services Authority $(\mathrm{OJK})$, each of which consists of 50 data samples. The data analysis technique used in this study is simple regression analysis to determine the magnitude of the influence of COVID-19 on non-performing loans. The results of the data analysis show that COVID-19 has a significant effect on non-performing loans, and the COVID-19 variable can be used as an external indicator of the increase in non-performing loans for commercial banks in Indonesia. The implication of the research is that other researchers can make COVID-19 an external indicator of an emergency beyond human ability that can affect the level of non-performing loans. For banking, this study can be used as a reference when considering credit risk management policy during the COVID-19 pandemic.
\end{abstract}

\section{Keywords}

COVID-19 pandemic, debtor's ability, determinant factor of non-performing loans, credit risk management

JEL Classification G21, G32, H81, I15

\section{INTRODUCTION}

Since the coronavirus outbreak, the Indonesian government has adopted a social distancing policy to break the chain of spreading COVID-19. Indirectly, this social distancing policy hampered several business sectors from operating. Some even had to lay off their employees to reduce operational costs. This systemic impact also affects debtor's ability in repaying loans originated from bank credit. The banking sector has begun to be very careful in channeling credit in order to avoid the risk of bad credits. The difficulty in paying the borrowers has made several banks, especially small-scale ones, experience an increase in bad credit cases. The occurrence of bad credit cases in several banks is a sign that the bank's operational activities are unwell.

In Indonesia, during the COVID-19 pandemic, the level of non-performing loans (NPL) in the national banking industry increased from 2.53\% in December 2019 to 2.7\% in February 2020. Several Indonesian banks, especially small-scale banks, had to go out of business due to credit problems that can no longer be resolved, such as bad credit cases that occurred at the Bank Perkreditan Rakyat (BPR) BKK Kebumen, MNC Bank, Artos Bank, Banten Bank, Dubai Syariah Panin Bank, and BJB Syariah Bank (Rossiana, 2020). Dahlan Siamat concludes that 
poor credit performance is defined as credit that experiences payment difficulties due to deliberate factors or due to external factors beyond the debtor's control (Siamat, 2011).

The COVID-19 pandemic is an external factor beyond the ability of debtors to control, which causes difficulties for debtors to repay credits originating from bank credits. Bad credit performance can also be caused by natural disasters such as the coronavirus outbreak. Former Governor of Bank Indonesia, Burhanuddin Abdullah in Iswi Haryani's quote stated that bad credit is caused by natural disasters or emergencies beyond human capacity (Hariyani, 2013).

Several researchers have previously conducted research related to this matter. Thus, Maria Indriyani Hewe Tiwu found that the COVID-19 pandemic had a positive and significant effect on NPLs of Bank Perkreditan Rakyat (Tiwu, 2020). Ade Novaliana and Rosadi reckon that the impact of COVID-19 has an effect on the increase in bad credit in the banking industry (Novalina, 2020). Hadiah Putri Pratamawati reckons that the factors that influence NPLs of BUMN Commercial Banks are inflation, exchange rates, loan to deposit ratio (LDR), Capital Adequacy Ratio (CAR) and Operational Cost of Operating Income/Biaya Operasional Pendapatan Operasional (BOPO) (Pratamawati, 2018). Vhietrin Gift found that the factors that influence lending to Bank Perkreditan Rakyat are Third Party Funds, interest rates and NPL (Gift, 2017). Romo Putra Mada found that the factors that influence NPLs are Operational Income, Operational Costs/Biaya Operasional Pendapatan Operasional (BOPO) and credit interest rates (Mada, 2015). Andreani Caroline Barus found that the factors that influence the NPL of commercial banks in Indonesia are external factors consisting of Bank Indonesia Certificate/Sertifikat Bank Indonesia and Inflation, and internal factors consisting of CAR, LDR, NIM, BOPO and Company Size (Barus, 2016).

Based on the COVID-19 case study, the investigation has been conducted to prove if COVID-19 has an impact on the level of non-performing loans (NPLs) of conventional commercial banks in Indonesia.

\section{LITERATURE REVIEW}

The coronavirus that has shaken every country has an impact on the economic decline in those countries. The banking crisis is due to a significant decline in economic activity. The systemic impact of the COVID-19 outbreak also has an impact on banking credit performance. Josua Pardede, an economist at Bank Permata, made a statement in the online media news outlet The Jakarta Post that the COVID-19 pandemic had caused a slowdown in the economic cycle, which had an impact on credit growth (Iswara \& Rahman, 2020).

Kenny et al. (2020) state that the banking crisis has a significant effect on the economic downturn. An Economic Observer of PT Bank Mandiri said that the COVID-19 pandemic presented great challenges in all aspects of life (Asmoro, 2020). The Financial Services Authority/Otoritas Jasa Keuangan (OJK) in online media coverage stated that the COVID-19 pandemic had a major impact on the growth of bank credit (Sitinjak \& Ginting, 2020).
The Financial Services Authority/Otoritas Jasa Keuangan $(\mathrm{OJK})$ noted that the ratio of non-performing loans in the national banking industry increased from 2.53\% in December 2019 to 2.7\% in February 2020. Meanwhile, several banks in Indonesia, especially small-scale banks, experienced a decline - the case of bad credit that occurred at the Bank Perkreditan Rakyat (BPR) BKK Kebumen, MNC Bank, Artos Bank, Banten Bank, Panin Syariah Dubai Bank, and Bank BJB Syariah (Rossiana, 2020).

Non-performing loans are loans classified as substandard credit, doubtful credit, and bad credit (Hariyani, 2013). Bad credit can be defined as a loan that experiences payment difficulties due to deliberate factors or external factors that are beyond the debtor's control (Siamat, 2011). Former Governor of Bank Indonesia Burhanuddin Abdullah, as quoted by Iswi Haryani, said that bad credit is caused by:

1) a natural disaster or emergency beyond human capacity; 
2) the debtor's business is deteriorating, difficult to develop, has many competitors and managerial difficulties;

3) practice of learning services between debtors and banks;

4) debtors do not have good intentions in carrying out their responsibilities (Hariyani, 2013).

Factors that influence non-performing loans of commercial banks in Indonesia are bank internal factors, debtors' internal factors, and external factors of non-banks and debtors (Barus, 2016).

Bartoletto et al. (2019) found that extraordinary events such as world wars and the global financial crisis could affect the credit expansion cycle. Dirk Bezemer and $\mathrm{Lu}$ Zhang found that "unsustainable credit growth leads to financial stability risks" (Bezemer \& Zhang, 2019). Valentina Colombo and Alessia Paccagnini conclude that "credit provision triggers an asymmetric effect on macroeconomics" (Colombo \& Paccagnini, 2020). Feng Dong and Zhiwei Xu have stated that "excessive credit expansion can trigger a crisis in the interbank market” (Dong \& Xu, 2020).

Ramazan Ekinci and Gulden Poyraz believe that "Banks should focus more on credit risk management, especially on controlling and monitoring non-performing loans" (Ekinci \& Poyraz, 2019). Ahlem Selma Messai and Fathi Jouini found that non-performing loans can be determined by factors such as GDP, unemployment, real interest rates, changes in credit composition, and credit loss reserve to the ratio of total loans (Messai \& Jouini, 2013). Asrip Putera and Muh Yani Balaka stated that the right strategic formula for resolving bad credit was institutional strengthening, a strict credit selection process, and improvement of service procedures (Putera \& Balaka, 2019).

One of the main functions of a bank is to allocate funds in the form of credit. According to the Constitution/Undang-undang Dasar Number 7 of 1992, Credit is the provision of money or equivalent claims, based on a loan agreement or agreement between a bank and another party, which requires the debtor to pay off his debt after a certain period of time with a certain amount of interest
(Siamat, 2011). The Financial Services Authority/ Otoritas Jasa Keuangan (OJK) has a statement that banks must pay attention to the quality of lending arrangements in the era of the COVID-19 pandemic (OJK, 2020).

\section{RESEARCH HYPOTHESES}
$H_{1}$ : COVID-19 affects non-performing loans of banks.

Hypothesis testing criteria:

$H_{0}$ : The case of COVID-19 has no effect on non-performing loans of banks.

$H_{1}$ : The case of COVID-19 has an effect on non-performing loans of banks.

\section{RESEARCH METHOD}

The type of research used in this study is case study research in which the researcher digs indepth information through the problems that are happening. This research aims to prove whether it is true that COVID-19 has an impact on the level of non-performing loans.

The population of this research is all Indonesian citizens indicated by COVID-19, whether they are people in examinations, people undergoing treatments, patients who have recovered or patients who have died due to COVID-19. The population of the non-performing loan variable are banking data for all banks operating in Indonesia for each period of the year.

The sample data used in this study are 50 research data samples, consisting of data on non-performing loans of conventional commercial banks from May 2016 to June 2020, which were sourced from Indonesian Banking Statistics/Statistik Perbankan Indonesia data. Then, the data of cumulative percentage of positive COVID-19 patients from March 9, 2020 to June 16, 2020, are sourced from the Ministry of Health.

Sampling is done using a purposive sampling technique, where the researcher chooses certain 
criteria at the time of sampling. The criteria are shown in Table 1.

Table 1. Purposive sampling

Source: OJK (n.d.), Ministry of Health of the Republic of Indonesia (2020).

\begin{tabular}{|c|c|c|}
\hline No. & Criteria & $\begin{array}{c}\text { Amount } \\
\text { of data }\end{array}$ \\
\hline 1 & $\begin{array}{l}\text { Cumulative number of positive COVID-19 } \\
\text { patients per two days in Indonesia }\end{array}$ & 50 days \\
\hline 2 & $\begin{array}{l}\text { The amount of NPLs of commercial banks } \\
\text { in Indonesia based on the type of use } \\
\text { and the object of its use }\end{array}$ & $\begin{array}{l}50 \text { data of } \\
\text { NPL }\end{array}$ \\
\hline
\end{tabular}

The data used in this study is secondary data sourced from the Ministry of Health of the Republic of Indonesia and the Financial Services Authority/Otoritas Jasa Keuangan (OJK). The research variables used are an independent variable $(X)$ : COVID-19, and a dependent variable $(Y)$ : Non-Performing Loans (NPLs).

The method of analysis used in this research is simple regression analysis. The classic assumption test is used to ensure that the data used in this study are normally distributed. The regression equation model used in this study is as follows:

$$
Y=a+b X,
$$

where $a=$ constant, $b=$ regression coefficient.

\section{RESEARCH RESULTS}

Descriptive statistic is used in this study to describe the object under study through data samples that have been processed by statistical test tools. The results of the descriptive statistical test are shown in Table 2.

The results of statistical tests show that the minimum value of the cumulative number of positive patients with COVID-19 from March $9^{\text {th }} 2020$ to June $16^{\text {th }}$ 2020 were 6 people (data as of March $9^{\text {th }}, 2020$ ) and the maximum number is in the range of 39,294 people (data as of June $16^{\text {th }}, 2020$ ). This shows that the data on positive patients with COVID-19 used in this study range from 6 to 39,294 positive patients with COVID-19. The average (mean) data for COVID-19 12,040.24 people are greater than the standard deviation value of 11,587 people, which shows that the distribution of the data used in this study is good.

Meanwhile, data on non-performing loans has a fairly good distribution. This can also be proven by the following chart (Figure 1).

Figure 1 shows that the data plots are normally distributed. According to Prof. Dr. Imam Ghozali, data are normally distributed if they spread around the diagonal line and follow the direction

Table 2. Descriptive statistics

\begin{tabular}{l|c|c|c|c|c}
\hline \multicolumn{1}{c}{ Variable } & N & Minimum & Maximum & Mean & Std. deviation \\
\hline COVID-19 cases & 50 & 6 & 39294 & 12040.24 & 11587.033 \\
\hdashline NPL & 50 & 122923 & 172554 & 138330.04 & 10390.214 \\
\hline
\end{tabular}

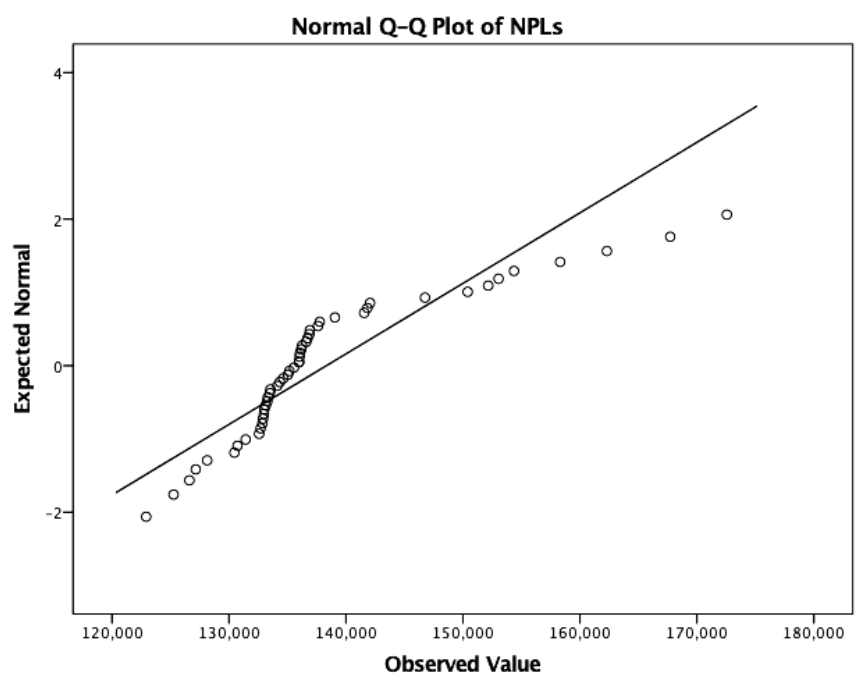

Figure 1. Data normality test 
Table 3. Validity test results

\begin{tabular}{|c|c|c|c|}
\hline & Variable & COVID-19 & NPLs \\
\hline \multirow{3}{*}{ COVID-19 } & Pearson correlation & 1 & $.858^{* *}$ \\
\hline & Sig. (2-tailed) & - & .000 \\
\hline & N & 50 & 50 \\
\hline \multirow{3}{*}{ NPLs } & Pearson correlation & $.858^{* *}$ & 1 \\
\hline & Sig. (2-tailed) & .000 & - \\
\hline & $\mathrm{N}$ & 50 & 50 \\
\hline
\end{tabular}

Note: ${ }^{* *}$ - correlation is significant at the 0.01 level (2-tailed).

Table 4. SPSS simple regression output results

\begin{tabular}{l|c|c|c|c|c|c|c|c:c}
\hline Variable name & Constant & Beta & t-count & t-table & Sig. & R-Square & F-count & F-table & Sig. \\
\hline COVID-19 & $129,068.399$ & 0.769 & 11.564 & 2.010 & 0.000 & 0.736 & 133.729 & 4.042 & 0.000 \\
\hline
\end{tabular}

of the diagonal line (Ghozali, 2018). And the results of the following validity test (Table 3 ) show that the level of each variable is significant, which means that the data used is valid.

\section{REGRESSION ANALYSIS}

The data used in this regression model are normally distributed and can be used to determine the relationship between variables (Table 4).

Table 4 shows that:

$$
\begin{gathered}
Y=a+b X, \\
Y=129,068.399+0.769 X, \\
\text { Significance } 0.000<0.05 .
\end{gathered}
$$

COVID-19 has a significant effect on non-performing loans at 0.769 or $76.9 \%$.

\section{HYPOTHESES TESTING}

COVID-19 affects non-performing loans of banks.

Hypothesis testing criteria:

\section{$H_{0}: \quad$ COVID-19 has no effect on non-performing loans of banks.}

$H_{1}$ : COVID-19 has an effect on non-performing loans of banks.

Based on the results of the simple regression output, it can be seen the cases of COVID-19 has an effect on banking non-performing loans. And the magnitude of the R-square value is 0.736 , which means that the non-performing loans variable can be explained by the COVID-19 variable as much as 0.736 or $73.6 \%$, and the remaining $6.4 \%$ can be explained by other factors outside of this research.

\section{DISCUSSION}

The Financial Services Authority/Otoritas Jasa Keuangan (OJK) stated that during the COVID-19 pandemic, the ratio of NPLs increased (Rossiana, 2020). The research results prove that each time the number of COVID-19 cases increases, each time the number of NPLs increases by 0.769 or $76.9 \%$ of the increase in COVID-19 cases. This proves that the large number of positive COVID-19 patients affects the rate of non-performing loans.

This proves that the COVID-19 case is one of the signs of a natural disaster factor beyond human ability, which affects the NPL level of conventional commercial banks. The results of this study are in line with the statement of Burhanuddin Abdullah's in Iswi Haryani that non-performing loans can be caused by natural disasters or emergencies beyond human capacities (Hariyani, 2013). Furthermore, the researcher also quoted Barus and Erick's statement that non-performing loans at commercial banks in Indonesia could be influenced by external non-bank and debtor factors (Barus, 2016).

It is concluded that the COVID-19 case was a non-banking external factor and non-debtor factor due to an emergency beyond human capacity, which led to an increase in non-performing loans. 


\section{CONCLUSION}

This study tried to find evidence as to whether the COVID-19 case is actually contributing to the rise in bad credit cases found in several conventional commercial banks in Indonesia. The results of the data analysis prove that it is true that the COVID-19 case has an impact on the increase in bad credit cases in several conventional commercial banks in Indonesia. Therefore, the COVID-19 case can be used as one of the external factors for banks and debtors that can affect the increase in bad credit, in addition to inflation, exchange rates, Bank Indonesia Certificates/Sertifikat Bank Indonesia, credit interest rates, Loan to Deposit Ratio (LDR), Capital Adequacy Ratio (CAR), Operational Cost of Operating Income/Biaya Operasional Pendapatan Operasional (BOPO), Net Interest Margin (NIM) and Company Size (Size) as stated by Prize Putri Pratamawati (Pratamawati, 2018) and Andreani Caroline Barus (Barus, 2016).

The results of this study are in line with Burhanuddin Abdullah's statement quoted by Iswi Haryani that the occurrence of bad credit is caused by natural disasters or emergencies beyond human capacity; the debtor's business is deteriorating and difficult to develop (Hariyani, 2013). Thus, it can be concluded that the occurrence of COVID-19 is one of the bank's external factors caused by emergencies such as COVID-19, which leads to a deterioration of a debtor's business situation, so that it has an impact on the increase in the number of non-performing loans of conventional commercial banks in Indonesia. Therefore, conventional commercial banks in Indonesia must be able to formulate the right strategic formula for dealing with bad credit problems as institutional strengthening and improving banking service procedures.

A slowdown in the economy due to the COVID-19 case will cause unsustainable credit growth, leading to financial stability risks and triggering an asymmetric effect on the macroeconomic system.

\section{AUTHOR CONTRIBUTIONS}

Conceptualization: Siti Epa Hardiyanti.

Data curation: Siti Epa Hardiyanti.

Formal analysis: Lukmanul Hakim Aziz.

Funding acquisition: Lukmanul Hakim Aziz.

Investigation: Siti Epa Hardiyanti.

Methodology: Siti Epa Hardiyanti.

Project administration: Lukmanul Hakim Aziz.

Resources: Lukmanul Hakim Aziz.

Software: Siti Epa Hardiyanti.

Supervision: Siti Epa Hardiyanti.

Validation: Lukmanul Hakim Aziz.

Visualization: Lukmanul Hakim Aziz.

Writing - original draft: Siti Epa Hardiyanti.

Writing - reviewing \& editing: Siti Epa Hardiyanti.

\section{ACKNOWLEDGMENT}

The researchers are grateful to University of Sultan Ageng Tirtayasa for financial support. In addition, the authors sincerely apologize for the errors and mistakes found in this paper. 


\section{REFERENCES}

1. Asmoro, A. (2020). Tantangan Perbankan Dan Kesiapan Menghadapi New Normal [Banking Challenges and Readiness for New Normals]. Institut Teknologi Sepuluh Nopember (ITS). (In Indonesian). Retrieved from https:// www.its.ac.id/drpm/wp-content/ uploads/sites/71/2020/06/200611New-Normal-dan-TantanganPerbankan-ITS.pdf

2. Bartoletto, S., Chiarini, B., Marzano, E., \& Piselli, P. (2019). Business cycles, credit cycles, and asymmetric effects of credit fluctuations: Evidence from Italy for the period of 1861-2013. Journal of Macroeconomics, 61, 103130. https://doi.org/10.1016/j.jmacro.2019.103130

3. Barus, A. C., \& Erick. (2016). Analysis of Factors affecting NonPerforming Loans of Commercial Banks in Indonesia. Jurnal Wira Ekonomi Mikroskil, 6(2), 113122. Retrieved from https://www. mikroskil.ac.id/ejurnal/index.php/ jwem/article/view/325/201

4. Bezemer, D., \& Zhang, L. (2019). Credit composition and the severity of post-crisis recessions. Journal of Financial Stability, 42, 52-66. https:// doi.org/10.1016/j.jfs.2019.05.010

5. Colombo, V., \& Paccagnini, A. (2020). Does the credit supply shock have asymmetric effects on macroeconomic variables? Economics Letters, 188, 108958. https://doi.org/10.1016/j.econlet.2020.108958

6. Dong, F., \& Xu, Z. (2020). Cycle of Credit Expansion and Misallocation: The good, the bad, and the ugly. Journal of Economic Theory, 186, 104994. https://doi. org/10.1016/j.jet.2020.104994

7. Ekinci, R., \& Poyraz, G. (2019). The Effect of Credit Risk on Financial Performance of Deposit Banks in Turkey. Procedia Computer Science, 158, 979-987. https://doi. org/10.1016/j.procs.2019.09.139

8. Gift, V. (2017). Faktor-faktor yang mempengaruhi penyaluran kredit pada Bank Perkreditan Rakyat (BPR) di Provinsi Riau Tahun 2006-2015. Jurnal Online
Mahasiswa Fekon, 4(1), 768-782.

Retrieved from https://jom.unri. ac.id/index.php/JOMFEKON/article/view/12831/12473

9. Hariyani, I. (2013). Restrukturisasi dan Penghapusan Kredit Macet (1st ed.). Kompas Gramedia.

10. Iswara, M. A., \& Rahman, R. (2020). COVID-19 batters Indonesia's loan growth to record low. The Jakarta Post. Retrieved from https://www.thejakartapost.com/ news/2020/04/06/covid-19-battersindonesias-loan-growth-to-recordlow.html

11. Kenny, S., Lennard, J., \& Turner, J. D. (2020). The macroeconomic effects of banking crises: Evidence from the United Kingdom, 1750-1938. Explorations in Economic History, 101357. https://doi.org/10.1016/j. eeh.2020.101357

12. Mada, R. P. (2015). Analisis Faktor-faktor yang mempengaruhi Non-Performing Loan di Indonesia: Analysis of the factors that affect Non-Performing Loans in Indonesia. University Diponegoro. Retrieved from http://eprints.undip. ac.id/46118/1/13_MADA.pdf

13. Messai, A. S., \& Jouini, F. (2013). Micro and Macro Determinants of Non-Performing Loan. International Journal of Economics and Financial Issues, 3(4), 852-860. Retrieved from https://www.econjournals.com/index.php/ijefi/article/ viewFile/517/pdf

14. Ministry of Health of the Republic of Indonesia. (2020). Media KIE COVID-19. Retrieved from https:// infeksiemerging.kemkes.go.id/ document/download/cover

15. Novalina, A. (2020). Indonesian Economy the Impact of COVID-19 (IHSG by ARDL). Jurnal Kajian Ekonomi dan Kebijakan Publik, 5(2), 247-259.

16. Otoritas Jasa Keuangan (OJK). (2020). Peraturan Otoritas Jasa Keuangan Nomor 18/POJK.03/2020 tentang Perintah tertulis untuk penanganan permasalahan bank. Retrieved from https://www.ojk. go.id/id/regulasi/Documents/Pages/ Perintah-Tertulis-untuk-Penanga-
nan-Permasalahan-Bank/FAQ\%20

-\%20POJK\%2018.pdf

17. Otoritas Jasa Keuangan (OJK). (n.d.). Statistik Perbankan Indonesia. Retrieved from https://www.ojk. go.id/id/kanal/perbankan/datadan-statistik/statistik-perbankanindonesia/Default.aspx

18. Pratamawati, H. P. (2018). Analisis Faktor-faktor yang mempengaruhi Non-Performing Loan pada Bank Umum BUMN Tahun 2012-2016 [Analysis of Factors Affecting NonPerforming Loans at State-Owned Commercial Banks in 2012-2016]. Universitas Negeri Yogyakarta. (In Indonesian). Retrieved from https://eprints.uny.ac.id/57723/1/ Hadiah\%20Putri\%20Pratamawati_14804241047_skripsi.pdf

19. Putera, A., \& Balaka, Muh. Y. (2019). Treatment strategies for bad loans to microfinancial institutions: Evidence from Kendari, Indonesia. Investment Management and Financial Innovations, 16(1), 144153. http://dx.doi.org/10.21511/ imfi.16(1).2019.11

20. Rossiana, G. (2020). Some Banks Have NPLs Above 5\%, What Is It? CNBC Indonesia. Retrieved from https://www.cnbcindonesia.com/ market/20180727142501-17-25737/ beberapa-bank-punya-npl-di-atas5-ada-apa

21. Siamat, D. (2011). Manajemen Lembaga Keuangan, Kebijakan Moneter dan Perbankan (5th ed.). FE UI.

22. Sitinjak, Y., \& Ginting, K. (2020). OJK: Terdampak Covid-19, Kinerja Sektor Perbankan Melambat [OJK: Affected by Covid-19, Banking Sector Performance Slows down]. The Iconomics. Retrieved from http://www.theiconomics.com/ capital-market/ojk-terdampakcovid-19-kinerja-sektor-perbankanmelambat/

23. Tiwu, M. I. H. (2020). Pengaruh Pandemic Covid 19 Terhadap Npl Bank Perkreditan Rakyat Di Indonesia [The effect of the Covid 19 pandemic on the NPL of BPR in Indonesia]. Jurnal Akuntansi, 8(2), 79-87. Retrieved from https:// ejurnal.undana.ac.id/JAK/article/ view/2869 